\title{
Writing Anxiety and its Signs: A Qualitative Study of a Female ESL Writer
}

Norhartini Aripin, Noor Hanim Rahmat

To Link this Article: http://dx.doi.org/10.6007/IJARBSS/v11-i1/8399

DOI:10.6007/IJARBSS/v11-i1/8399

Received: 20 November 2020, Revised: 18 December 2020, Accepted: 04 January 2021

Published Online: 21 January 2021

In-Text Citation: (Aripin \& Rahmat, 2021)

To Cite this Article: Aripin, N., \& Rahmat, N. H. (2021). Writing Anxiety and its Signs: A Qualitative Study of a Female ESL Writer. International Journal of Academic Research in Business and Social Sciences, 11(1), 334345.

Copyright: (c) 2021 The Author(s)

Published by Human Resource Management Academic Research Society (www.hrmars.com)

This article is published under the Creative Commons Attribution (CC BY 4.0) license. Anyone may reproduce, distribute, translate and create derivative works of this article (for both commercial and non-commercial purposes), subject to full attribution to the original publication and authors. The full terms of this license may be seen

at: $\underline{\text { http://creativecommons.org/licences/by/4.0/legalcode }}$

Vol. 11, No. 1, 2021, Pg. 334 - 345

Full Terms \& Conditions of access and use can be found at http://hrmars.com/index.php/pages/detail/publication-ethics 


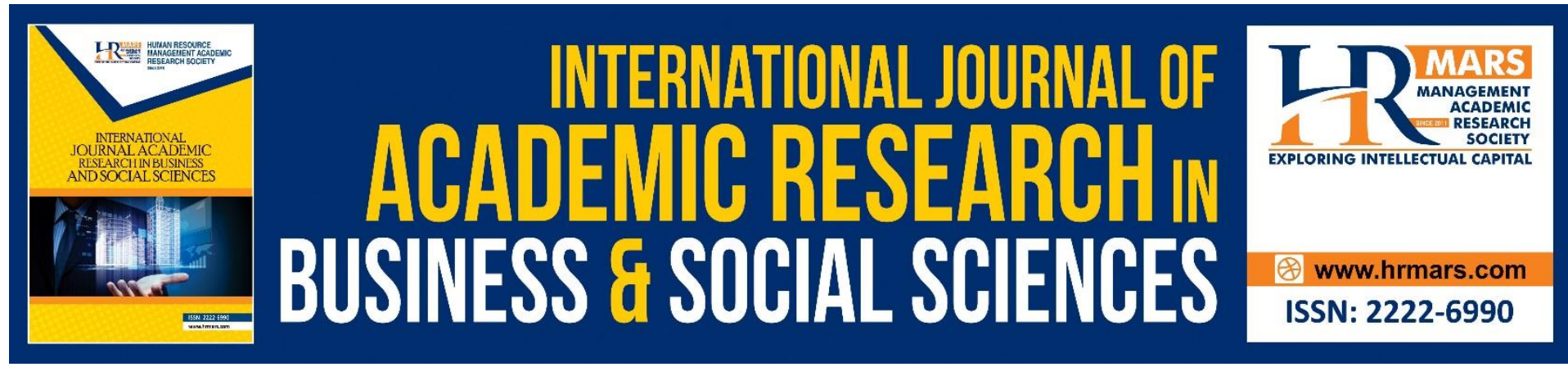

\title{
Writing Anxiety and its Signs: A Qualitative Study of a Female ESL Writer
}

\author{
Norhartini Aripin ${ }^{1}$, Noor Hanim Rahmat ${ }^{2}$ \\ ${ }^{1}$ Akademi Pengajian Bahasa,UiTM Pasir Gudang, Jalan Purnama, Persiaran Seri Alam, 81750 \\ Masai, Johor. Malaysia, ${ }^{2}$ Akademi Pengajian Bahasa, UiTM Shah Alam, 40450 Shah Alam, \\ Selangor. Malaysia \\ Email: hartiniaripin494@gmail.com,patanim@gmail.com
}

\begin{abstract}
Writing for English as a second language (ESL) is a challenging, yet demanding skill for ESL writers. This skill requires learners to excel in language use such as vocabulary, grammar, sentence structure, strategies and lexical. In other words, ESL writers should possess adequate language proficiency in order to produce a good written text. This demand causes ESL writers to experience writing anxiety. Hence, it is important for teachers and educators to acknowledge common signs of writing anxiety portrayed by the ESL writers during the writing process. Recognising early signs of writing anxiety could alleviate ESL writers from having much worries and anxious during the writing process. This qualitative study therefore aims to identify signs of writing anxiety shown by a female ESL writer during a writing process. Data is collected by reporting on narrative enquiry from an observation of a writer going through the process of writing using Think Aloud protocol. A semi-structured interviewd was carried out as part of data collection. The findings revealed that writing anxiety occurred during the writing process from the writing behaviour shown by the ESL writer. Results of this study have given a great impact on teaching and learning of ESL academic writing
\end{abstract}

Keywords: Writing Anxiety, ESL Writers, ESL Writing, Writing Process, Narrative Enquiry, Signs, Writing Behaviour.

\section{Introduction}

Background of the Study

Writing is the most challenging skill among other language skills; reading, speaking and listening. This skill involves cognitive process in which writers are not only required to generate and construct ideas, but to communicate the ideas successfully to the readers. In other words, the writers should ensure all the ideas, opinion, thoughts that they have in their mind could be delivered and clearly understood by the readers, as claimed by Rahmat (2016), writing promotes social cognitive process where writers should put readers in their mind so that their writing is considered complete.

Writing in a second language (ESL) is more challenging for most ESL writers. According to AlSawalha (2012), writing in a second language is difficult compared to writing in one's native language (L1). This is because, in learning ESL writing, writers are expected to excel in the 
writing process and at the same time coping with language 'matters'. Knowing English as an isolate language for ESL writers, they surely face more difficulties to perform well in their writing since they need to aware of grammar, sentence structure, vocabulary and other languge mechanics.

The above situation has put ESL writers in a situation that hinders them form performing well in the writing process. This situation is known as writing anxiety, a problem faced by-many ESL writers. Cheng (2004) who conducted deep exploration about this writing problem determining types of writing anxiety faced by ESL writers. He classified writing anxiety into three main types; cognitive anxiety, somatic anxiety and avoidance behaviour.These types of writing anxiety can be investigated during the writing process. ESL writers who experience writing anxiety in the writing process will reveal signs that can be related to writing anxiety. The writing behaviour of ESL writers will provide in-depth details that help to address writing anxiety in the writing process.

\section{Problem Statement}

In learning writing, ESL writers need to ensure that readers receive the intended message successfully regardless of the language difficulties that they face along the way. Knowing ESL writing as a demanding process, it is common for ESL writers to experience writing anxiety when they have to engage in a writing process. This language problem is one of the obstacles that ESL writers need to encounter in ESL writing.

Although writing anxiety is a conspicuous problem faced by ESL writers, it is difficult to determine or identify the presence of anxiety during the writing process. However, writing anxiety can be recognised from the writing behaviour shown by the ESL writers when they engage in the writing process. The writers' behaviour is believed to provide insightful information related to writing anxiety.

Although there are numerous resaerchers (e.g; Cheng,2004; Mastan, Maarof and Embi,2017; Rezaei and Jafari,2014, Hyland, 2003) have explored and investigated writing anxiety in ESL writing, there are still limited studies that use narrative enquiry and videotaping as the main instruments in exploring writing anxiety. Hence, the study will explore writing anxiety by analysing writer's writing behaviour during a writing process.

The study aims to explore ESL writers' anxiety in writing by analysing writing behaviour which can be associated with writing anxiety. Besides, the researcher intends to identify how this problem affects the writer's writing performance.

Specifically, this study is done to answer the following questions;

a. What are the signs shown by a female ESL writer in the writing process that can be associated with writing anxiety?

b. What are the reactions of ESL writers towards writing in English language?

\section{Literature Review}

ESL Writing

Writing as a second language (ESL) is a complicated task for ESL writers. It is important for every writer to be competent in writing as their language attainment is measured by their proficiency in writing. To excel in ESL writing, ESL writers are expected to have good knowledge in the language itself. However, in getting the language, they commonly face some language difficulties that deter them to perform well in writing. The common problems faced 
by the ESL writers are limited vocabulary ( Liu, 2013; Mastan, Maarof and Embi, 2017), unable to use appropriate words and phrases, inability to generate ideas using English language ( Mastan et.al,2017); problems in grammar ( Mastan et.al,2017). The difficulties caused them to experience writing anxiety.

\section{Writing Anxiety}

Writing anxiety is known as one of language barriers that prevent writers from performing well in a writing task. Writing anxiety was originated from Daly and Miller (1975) who defined this language barrier as an act of avoiding writing by individuals dealing with some amount of writing accompanied by their potential to be evaluated. When a writer experiences writing anxiety, she or he tends to show and express unpleasant feelings such as stress, nervous, worried, and trembling during the writing process (Rezaei \&Jafari, 2014 ;Badrasawi et.al, 2016).

Additionally, writing anxiety can be caused and influenced by many factors. A study by Rezaei and Jafari (2014) affirms that writing anxiety can be caused by several factors which are: (1) a very limited time to plan, compose and review; (2) lack of writing skills including writing practice (Liu and $\mathrm{Ni}, 2015$ ), brainstorming ideas, translating ideas as well as limited writing mechanics such as vocabulary and punctuation (Rezaei et.al, 2014; Daud, et.al 2003; Kurniasih, 2017); (3) teacher's negative evaluation (Kirmizi \& Kirmizi, 2015).

As far as writing anxiety is concerned, this language problem definitely gives various effects to the writers. Huwari and Al-Shboul (2015) presents three types of major effects of writing anxiety experienced by PhD students in University Utara Malaysia (UUM). The effects are categorised into; (1) personal effect, (2) social effect, (3) academic effect. The findings are presented in the following table ( Table 1).

\begin{tabular}{|c|c|}
\hline EFFECTS & SUB-THEMES \\
\hline $\begin{array}{l}\text { PERSONAL } \\
\text { EFFECTS }\end{array}$ & $\begin{array}{l}\text { 1.Anxiety; the influence of } L 1 \text {, make grammatical mistakes, unable to } \\
\text { express ideas. } \\
\text { 2. Health issues; headache, high blood pressure, low back pain, } \\
\text { sleeping disorder and lose weight or gain extra weight. } \\
\text { 3.Depression; receive many comments from the supervisors on the } \\
\text { writing. }\end{array}$ \\
\hline SOCIAL EFFECTS & $\begin{array}{l}\text { Isolation-Avoiding people whom they do not like to interact with. } \\
\text { Students prefer to isolate themselves when writing in which affects } \\
\text { society. } \\
\text { Like to be alone and not talk with people around them including } \\
\text { families and friends. } \\
\text { Feel too embarrassed from friends' or supervisors' comments on } \\
\text { writing. }\end{array}$ \\
\hline CADEMIC & Low academic performance- writing anxiety will affect performance. \\
\hline
\end{tabular}

Table 1: Huwari and Al-Shboul's (2015) findings on effects of writing anxiety 
Types of Writing Anxiety

According to Cheng (2004), writing anxiety can be classified into three main types namely cognitive anxiety, somatic anxiety and avoidance behaviour. The details of each type is presented in the following section;

\begin{tabular}{cl}
\hline Types of Anxiety & \multicolumn{1}{c}{ Explanation } \\
\hline Somatic Anxiety & $\begin{array}{l}\text { One's perception of the physiological effects of } \\
\text { the anxiety experience such as nervous and tense. }\end{array}$ \\
Cognitive Anxiety & $\begin{array}{l}\text { Mental/cognitive aspects of anxiety experience } \\
\text { such as negative expectation towards writing and } \\
\text { anxious of negative evaluation or perception. }\end{array}$ \\
Avoidance-behaviour Anxiety & $\begin{array}{l}\text { Behavioral aspect in the avoidance of writing such } \\
\text { as avoiding writing classes and writing activities. }\end{array}$ \\
\hline
\end{tabular}

Table 2: Types of Writing Anxiety in ESL writing (Cheng, 2004)

Other resaerchers such as Wahyuni \& Umam,2017; Rahim \& Hayas , 2014; Jebreil et.al, 2015; Rezaei, et.al, 2014; . according to them ESL writers usually experience cognitive anxiety compared to somatic anxiety and avoidance behaviour. The difficulties to master the language makes the writers develop negative perceptions about writing. In fact, they are also worried about other's expectation including the negative evaluation or feedback.

Signs of Writing Anxiety

It is not easy to identify the presence of writing anxiety in a writing process. However, the researcher believes that writing anxiety can be recognised from writers' behaviour that can be associated with anxiety. Besides that, writers who are anxious during the writing process usually show some symptoms or signs of writing anxiety such as shaking, sweating, trembling and guilty (Cheng, 2004).

There are researchers such as Kurniasih (2017); Cheng (2004); Huwari and Abd Aziz (2015) who investigate writing anxiety from many angles including its signs and symptom. Kurniasih (2017) in her study found that students who are panic, nervous and worried during the writing session will not be able to control their emotion which cause them to produce poor writing. In addition, students who experience writing anxiety tend to use body language to portray their anxious feelings during the writing process. Hence, it is believed that writing anxiety of the writers can be figured out from their attitude and behaviour throughout the writing process. Indah et.al (2018) state that students usually use facial expressions to show fear, surprise and shy. In fact, repeated movement such as shaking leg and tapping a pen or pencil on the desk also another sign of nervousness (Najarzadegan and Dabaghi, 2014).

Although it is not easy to identify writing anxiety in a writing process, some researchers; Sahid et.al,2018; Indah et.al, 2018; Caganaga, 2015; Ekman, 2004; have reported writers' behaviour which can be associated with writing anxiety. For example, Sahid et.al (2018) reported that anxious individuals tend to use hand movement or gesture in order to cover their anxiety or nervousness. The researchers also mentions in their study that a female participant 
repeatedly touched her scarf when she felt anxious during a seminar presentation as she tried to control and hide her nervousness by touching her head using both her hands.

\section{Methodology}

Research Design, Sampling and Instrumentation

The method used in this research was qualitative descriptive research. Purposive sampling was used in the study as it involved a female student from a public university. The selected participant was a semester three students who enrolled in one of the English courses namely Integrated Language Skill III (ELC231). This English course mainly focuses on writing. Students were taught writing process and there were a few assessment that required them to write. Additionally, in week six, the students were requisite to sit for a writing test called 'expository writing' to test their writing ability and proficiency.

There were two main instruments administered in this study to gather pertinent information. The first instrument conducted was narrative enquiry, the process that was used by the researcher to narrate the particpant's writing behaviour during the writing process. This is done through watching a writer going through the writing process using Think Aloud Protocol. Secondly, a semi-structured interview was carried out to obtain additional details for the study. The interviews questions were adopted from Al-Asmari (2013).

\section{Procedure}

To collect data for the study, a female student voluntarily presented to be the participant for the study. After receiving a short brief on how the procedure would be conducted, the participant was instructed to write an essay. The time allocated for the wriitng session was two hours. The participant was aware of the presence of the researcher (to observe the writing behaviour and attitude) besides videotaping the process. during the writing process, the researcher jotted down important notes on the writer's behaviour. After the participant finished her writing, a semi-structured interview was also conducted to get first-hand indepth information. The student gets to share her experience and thought as a confirmation to produce evidence to confirm earlier findings. After the process, a procedure called narrative enquiry was conducted to analyse all the movements made by the participants. The gathered information from the narrative enquiry was later transcribed and interpreted by the researcher to attain the findings for the study. 


\section{Findings and Discussion}

What are the signs shown by a female ESL writer in the writing process that can be associated with writing anxiety?

\begin{tabular}{|c|c|}
\hline Videotaping/Narrative Enquiry & Description \\
\hline $\begin{array}{l}\text { 1) Hand movement } \\
\text { - Touching } \\
\text { (00:42)- The female student touched her } \\
\text { scarf using both her hands when she could } \\
\text { not get the ideas to write. } \\
\text { - Fidgeting pen } \\
\text { (00:52:20)-She firmly questioned herself } \\
\text { the best way to end her essay properly } \\
\text { while fidgeting her pen a few times. }\end{array}$ & $\begin{array}{l}\text { Sahid et.al (2018) reported in their study that } \\
\text { a female participant repeatedly touched her } \\
\text { scarf when she felt anxious during a seminar } \\
\text { presentation. She tried to control and hide } \\
\text { her nervousness by touching her head using } \\
\text { both her hands. } \\
\text { The most common touching behaviour } \\
\text { performed are scratching, twirling hair, } \\
\text { fidgeting with fingers or hands, coughing and } \\
\text { throat clearing, resulting from feelings of } \\
\text { anxiety, nervousness and lack of control } \\
\text { (Ekman, 2004). }\end{array}$ \\
\hline $\begin{array}{l}\text { 2. Body posture } \\
\text { (04:48) - The female student showed a } \\
\text { slumped posture when she was } \\
\text { desperately recalling for some ideas to } \\
\text { write. } \\
\text { (07:19) -The female presenter slightly } \\
\text { crouched her body signing that she was a } \\
\text { bit unsure about her writing. }\end{array}$ & $\begin{array}{l}\text { Rigid body and slumped posture indicate } \\
\text { defeat, nervous or depression (Indah } \\
\text { et.al,2018) }\end{array}$ \\
\hline $\begin{array}{l}\text { 3. Eye contact } \\
\text { (00:57) - The female writer avoid any eye- } \\
\text { contact with the researcher although she } \\
\text { seems confused with the instruction. She } \\
\text { preferred to look everywhere instead of } \\
\text { making eye contact with the researcher. }\end{array}$ & $\begin{array}{l}\text { Students who are coping with anxiety will } \\
\text { avoid any eye-contact to reduce the tense } \\
\text { (Sulistyorini, 2018) }\end{array}$ \\
\hline $\begin{array}{l}\text { 4. Facial Expressions } \\
\text { (00:06:05)-She grinned at herself every } \\
\text { time she get confused with sentences she }\end{array}$ & $\begin{array}{l}\text { A facial expression such as raising and } \\
\text { lowering brows is strong to express anger, }\end{array}$ \\
\hline
\end{tabular}


made. She was seen making faces with her own writing. fear, surprise, disgust, sadness, distress and enjoyment (Ekman, 2004)

Learners usually use facial expressions as the way to express emotion and feelings like happiness, anger, surprise, fear and sadness (Caganaga \& Barabar, 2015)

Based on the findings obtained from the narrative enquiry, the researcher revealed that writing anxiety occurred during the writing process of a female ESL writer due to her writing behaviour and attitude throughout the process. Although the presence of writing anxiety is difficult to be identified, the researcher believes that the writing behaviour such as fidgeting pen, making faces, making body and hand movements can be related to writing anxiety. This has been supported by Ekman (2004) who states that the most common touching behaviour such as scratching, twirling hair, fidgeting with fingers or hands, coughing and throat clearing, are those signs shown by the writers, resulting from feelings of anxiety, nervousness and lack of control. Besides that, changing of body postures during the writing show that the writer feels uneasy, nervous or depressed ( Indah et.al, 2018. Findings revealed that the signs shown by the writer during the writing process can be associated with writing anxiety.

What are the reactions of ESL writers towards writing in English language?

\begin{tabular}{|l|l|}
\hline \multicolumn{1}{|c|}{ Questions } & \multicolumn{1}{|c|}{ Semi-structured Interview } \\
\hline $\begin{array}{l}\text { 1. How did you feel about writing in } \\
\text { English? }\end{array}$ & $\begin{array}{l}\text { " It is quite hard especially when I need to } \\
\text { memorise all the writing techniques. I also } \\
\text { have problems with grammar when I write" }\end{array}$ \\
\hline $\begin{array}{l}\text { 2. What are the normal habits that you do "Normally, I just muttering to myself, recalling } \\
\text { when you do not have ideas to write? } \\
\text { for some ideas, or I just write as many draft I } \\
\text { can." }\end{array}$ & $\begin{array}{l}\text { "I'worried about time, I think two hours is not } \\
\text { enough especially when I do not have ideas } \\
\text { what to write about the given topic. } \\
\text { Sometimes I forget the writing technique that } \\
\text { most during the writing process? }\end{array}$ \\
\hline $\begin{array}{l}\text { 4. Whe learnt in class and I know my lecturer } \\
\text { encounter when writing in English? }\end{array}$ & $\begin{array}{l}\text { "I have problems with vocabulary and } \\
\text { grammar. Although we do more writing } \\
\text { practice in class, but I still nervous when I have } \\
\text { to write an essay during a writing test." }\end{array}$ \\
\hline
\end{tabular}

Al-Asmari (2013) believes that interview is one of the effective ways to get individuals' persectives and experiences. Based on the findings gathered form the interview session, it was found that the female writer has some difficulties to write in English language where her 
main concern were more on the language itself; vocabulary and grammar and the writing techniques. Besides that, the writer had a little issues when it comes to a writing test in which she was worried about the time allocated for the test and lacking of ideas to write. Those were coomon challenges faced by ESL writers during the writing process as proven by Wahyuni and Umam (2017), some problems faced by ESL writers are fear of comments, time pressure, low self-confidence and problem with topic choice.

\section{Discussion}

Findings showed that writer's attitude and behaviour during the writing process can be associated with writing anxiety. Knowing ESL writing is a challenging process, it is normal for ESL writers to experience writing anxiety especially when they are tested within the allocated time frame. Although there are limited studies that explore writing anxiety using narrative enquiry, the researcher managed to obtain required data to prove the presence of writing anxiety during the writing process .

It is descripted above that some behaviours shown by the writer can be used to relate to writing anxiety. For example writer's body posture, hand movements and facial expression tell the anxious and nervous feelings which are related to writing anxiety. This shows that writers' behaviour can provide in-depth information about writing anxiety. Researchers such as (Indah et.al ,2018; Sahid et.al, 2018; Ekman, 2004; ) mention in their studies that, some behaviour or writing habits can be associated with writing anxiety.

\section{Conclusion}

Summary of Findings

It is common for ESL writers to experience writing anxiety in their ESL writing since to master the language itself is the real struggle for them. The most important thing is that,teachers and educators should be aware and understand the presence of writing anxiety during the writing process so that they could prepare with the best practice to alleviate the problem. Besides that, writing teachers should know how to identify the students with anxiety by observing their behaviour and attitude during the writing process. This could help writing teachers to come out with better strategies and techniques of writing to teach their students. This will increase their confidence and help them reduce their anxiety level to control unnecessary gestures that may hinder them from performing better.

Based on the discussion in the previous segment of the study, writing anxiety was affirmed to be one of the language barriers to the ESL writers. Hence, this study significantly helps educators and teachers to understand students' psychology in writing by examining and observing their attitudes and behaviour during a writing process. This could assist them to figure out ways and solutions to reduce this language barrier. Besides that, this study also provides more details and ideas to other researchers about writing anxiety which is believed to leave a great impact on teaching and learning of ESL writing.

\section{Suggestions for Future Research}

Future research should explore a more thorough investigation of the implications of using narrative enquiry in studying learners' behaviour and attitude in writing. Besides that, another instrument such as observation can be implemented for such studies in order to have in-depth details on writing anxiety. Additionally, data from different gender of speakers could 
be an insightful comparison to understand and associate writing axiety with writing behaviour better.

\section{Corresponding Author}

Norhartini Aripin

Email: hartiniaripin494@gmail.com

Phone Number: (+60)0126599016

\section{References}

Al Asmari, A. (2013). Investigation of Writing Strategies, Writing Apprehension, and Writing Achievement among Saudi EFL-Major Students, International Education Studies, 6(11), 130-143. Retrieved Oct 20,2020 from https://files.eric.ed.gov/fulltext/EJ1068732.pdf

Al-Sawalha, A. M. S., \& Chow, T. V. V. (2012). The effects of writing apprehension in English on the writing process of Jordanian EFL students at Yarmouk University. International Interdisciplinary Journal of Education, 1(1), 6-14. Retrieved July 25, 2018 from http://www.iijoe.org/IIJE_02_v1_i1_2012.pdf

Badrasawi, K. J., Zubairi, A., \& Idrus, F. (2016). Exploring the Relationship between Writing Apprehension and Writing Performance: A Qualitative Study. International Education Studies, 9(8), 134. doi:10.5539/ies.v9n8p134. Retrieved July 7, 2017,from http://www.ccsenet.org/journal/index.php/ies/article/view/61790

Caganaga, C.K.,\& Barabar, A.(2015).Using Non verbal Communication in EFL Classroom. Cypriot Journal of Educational Sciences, 10(2), 136-147. Retrieved Nov 22, 2020 from file://C:/Users/user/Desktop/Using_Nonverbal_Communication_in_Efl_Cla.pdf

Cheng, Y. (2004). Factors Associated with Foreign Language Writing Anxiety. Foreign Language Annals, 35(6),647-656. Retrieved August 1,2018 from https://onlinelibrary.wiley.com/doi/full/10.1111/j.1944-9720.2002.tb01903

Daly, J. A., \& Miller, M. D. (1975). Apprehension of Writing as a Predictor of Message Intensity. The Journal of Psychology,89(2), 175-177. doi:10.1080/00223980.1975.9915748

Daud, N. S. M., Daud, N. M., \& Kassim, L. N. A. (2005). Second language writing anxiety: Cause or effect? Malaysian Journal of ELT Research, Inaugural. Retrieved from https://journals.melta.org.my/index.php/majer/article/view/189/101

Aydin, B. (1999). A study of the sources of foreign language classroom anxiety in speaking and writing classes, (Unpublished doctoral dissertation). Anadolu University, Eskisehir.

Aydin, B. (1999). A study of the sources of foreign language classroom anxiety in speaking and writing classes, (Unpublished doctoral dissertation). Anadolu University, Eskisehir.

Aydin, B. (1999). A study of the sources of foreign language classroom anxiety in speaking and writing classes, (Unpublished doctoral dissertation). Anadolu University, Eskisehir.

Aydin, S., \& Zengin, B. (2008). Anxiety in foreign language learning: A review of literature. The Journal of Language and Linguistic Studies, 4 (1), $81-94$.

Ekman, P. (2004). Emotional and Conversational Nonverbal Signals. Language, Knowledge and Representation. Philosophical Studies Series, Vol99,39-47. Retrieved Dec, $1^{\text {st }} 2018$, from https://www.paulekman.com/wp-content/uploads/2013/07/Emotional-AndConversational-Nonverbal-Signals.pdf

Huwari, I., \& Al-Shboul, Y. (2015). The effects of writing apprehension among Jordanian Phd students' perspectives. Journal of Global Research in Education and Social, 3(1), 22-32. Retrieved February 12, 2018, from 
http://www.zu.edu.jo/MainFile/Profile_Dr_UploadFile/Researcher/Files/ResearchFile _3794_10_10.pdf

Huwari, I., \& Al-Shboul, Y. (2015). The effects of writing apprehension among Jordanian Phd students' perspectives. Journal of Global Research in Education and Social, 3(1), 22-32. Retrieved February 12, 2018, from http://www.zu.edu.jo/MainFile/Profile_Dr_UploadFile/Researcher/Files/ResearchFile _3794_10_10.pdf

Hyland, K. (2003). Writing and teaching writing. In J. C. Richards (Ed.), Second language writing (pp. 1-30). Cambridge: Cambridge University Press. Retrieved Nov 15, 2020

Indah, O. D., Crestiani, J., \& Ramadhana, M. A. (2018). Nonverbal Communication Used by Students of Informatics Study Program in Studying English through Lesson Study. Jurnal Studi Guru Dan Pembelajaran,1(1). Doi:10.30605/jsgp.1.1.2018.21. Retrieved Dec $2^{\text {nd }}$ 2018, from http://jsgp.web.id/index.php/jsgp/article/view/21/6

Jebreil, N., Azizifar, A., Gowhary, H., \& Jamalinesari, A. (2015). A Study on Writing Anxiety among Iranian EFL Students. International Journal of Applied Linguistics \& English Literature, 4(2). doi:10.7575/aiac.ijalel.v.4n.2p.68

Kirmizi, O., \& Kirmizi, G. D. (2015). An Investigation of L2 Learners' Writing Self-Efficacy, Writing Anxiety and Its Causes at Higher Education in Turkey. International Journal of Higher Education, 4(2). Retrieved August 18, 2019, from https://files.eric.ed.gov/fulltext/EJ1060569.pdf

Kurniasih. (2017). Writing Anxiety in Relation to High Performing Students' English Compositions.BRIGHT: Journal of English Language Teaching Linguistics and Literature, 1(1), 1-8. Retrieved July 7, 2017, from http://jurnal.stkippgritulungagung.ac.id/index.php/bright/article/view/243

Liu, M., \& Ni, H. (2015). Chinese University EFL Learners' Foreign Language Writing Anxiety: Pattern, Effect and Causes. English Language Teaching, 8(3). https://pdfs.semanticscholar.org/8ccd/85145d92cececf1ab2c3a97e0cf96d5508f9.pdf

Liu, X. (2013). Evaluation in Chinese university EFL students' English argumentative writing: An appraisal study. Electronic Journal of Foreign Language Teaching, 10(1), 40-53. http://e-flt.nus.edu.sg/v10n12013/liu.pdf

Mastan, M., Maarof, N., \& Embi, M. (2017). The effect of writing strategy instruction on ESL intermediate proficiency learners' writing performance. Journal of Educational Research and Review, 5(5), 71-78. Retrieved February 1, 2018, from file://D:/user/Downloads/Mastanetal1.pdf

Najarzadegan, S., \& Dabaghi, A. (2014). Effective nonverbal communications and English language classrooms. International Journal of English Language \&Translation Studies,2(2), 110-118. Retrieved November 28, 2018 from http://relp.khuisf.ac.ir/article_533617_6d8d5d0c332119950625607bddd30760.pdf

Rahim, S. A., \& Hayas, K. M. (2014). Investigating student's second language writing anxiety: a case study. In: Persidangan MICELT 2014, 13-15 Sept 2014, Hotel Palace of Golden Horses, Kuala Lumpur.

Rahmat, N. H. (2016). Analyzing Audience Awareness In Academic Writing Among Undergraduates. Jurnal Pendidikan Bahasa dan Sastra, 16(1), 88-95. Retrieved July 25, 2018 from http://ejournal.upi.edu/index.php/BS_JPBSP/article/view/3065/2094

Rezaei, M. M., Jafari, S. M., \& Younas, M. (2014). Iranian EFL Students' Writing Anxiety: Levels, Causes and Implications. English for Specific Purposes World, $\quad 42(15), \quad$ 1-10. Retrieved July 27, 2018 from 
https://www.sciencedirect.com/science/article/pii/S1877042814026688

Sahid, S., Aldiansyah, A., \& Iskandar, I. (2018). Understanding gender differences in students anxiety in a seminar presentation. International Journal of Humanities and Innovation (IJHI),1(1), 35-46. doi:10.33750/ijhi.v1i1.6. Retrieved July 12, 2019 from file://D:/user/Downloads/6-ArticleText-19-2-10-20180522.pdf

Wahyuni, S., \& Umam, M. K. (2017). An Analysis On Writing Anxiety Of Indonesian Efl College Learners. Journal Of English Education and Linguistics Studies. 4 (1), 103-126. file://D:/user/Downloads/333-1081-2-PB\%20(2).pdf

Wang, W., \& Wen, Q. (2002). L1 use in the L2 composing process: An exploratory study of 16 Chinese EFL writers. Journal of Second Language Writing, 11(3), 225-246. Retrieved July18,2018 from https://sci-hub.tw/10.1016/s1060 3743(02)00084-x 